\title{
FAKTOR-FAKTOR YANG MEMENGARUHI KEPUTUSAN KONSUMEN DALAM PEMBELIAN PRODUK SUSU BUBUK PERTUMBUHAN
}

\author{
Dedy Aguspriandono Suprapto ${ }^{\left.1,2^{*}\right)}$, Rita Nurmalina ${ }^{2}$, Idqan Fahmi ${ }^{2}$ \\ ${ }^{1}$ PT Indolakto Plant Jakarta, Jakarta Timur 13710, Indonesia \\ ${ }^{2}$ Program Studi Manajemen Bisnis, Institut Pertanian Bogor, Bogor 16151, Indonesia \\ *)E-mail: asteronova@yahoo.com
}

\begin{abstract}
Abstrak
Penelitian ini dilakukan untuk menentukan faktor-faktor atribut produk yang memengaruhi konsumen dalam pengambilan keputusan pembelian susu bubuk pertumbuhan. Temuan tersebut sekaligus akan menjadi dasar bagi perumusan strategi pemasaran yang dapat dilakukan oleh produsen susu bubuk pertumbuhan. Penelitian ini dilakukan di Jakarta selama bulan Desember 2013 sampai dengan Februari 2014 dan melibatkan 140 responden yang merupakan konsumen susu bubuk pertumbuhan. Data dianalisis menggunakan regresi logistik. Hasil penelitian menunjukkan bahwa faktor utama yang memengaruhi konsumen dalam memutuskan pembelian susu bubuk pertumbuhan adalah komposisi dan nilai gizi, efek dan manfaat pada anak, dan keamanan produk. Strategi pemasaran yang dapat dilakukan oleh perusahaan yang memproduksi susu bubuk pertumbuhan adalah dengan mengedukasi konsumen tentang nilai penting komposisi dan nilai gizi yang terkandung dalam susu bubuk pertumbuhan, mereformulasi kandungan zat dalam susu bubuk pertumbuhan sehingga menghasilkan efek yang positif bagi balita yang mengonsumsinya dan mengikuti persyaratan dan perizinan depkes dan Badan Pengawasan Obat dan Makanan (BPOM) untuk memastikan bahwa produk yang dipasarkan adalah produk yang aman.
\end{abstract}

Kata kunci: atribut produk, susu bubuk pertumbuhan, keputusan pembelian

\section{Determinant Factors of Purchase Decision of Toddler Formula Milk}

\begin{abstract}
The objectives of this study were to examine the factors of product atribute that affecting consumers in purchase decision making of growth formula for their toddlers. The study was conducted in Jakarta during December 2013 until Februari 2014 and involved 140 respondents of growth formula consumers. Data were analyzed by using logistic regression test. The results indicated that the main factors that influenced the consumers in purchase decision making of growth formula for their toddlers were compositional and nutritional value, suitability of milk that consume by their toddler, and product safety. Marketing strategy which can do by producer is educating consumer about the important composition and nutritional value contained in growth formula, reformulating ingredient contained in growth formula so that resulting a positive effect for a toddler who consume it, following requirement and licensing Ministry of Health and The National Agency of Drugs and Food Control (BPOM) to ensure that products which are available in market are the safe products.
\end{abstract}

Keywords: growth formula, product attributes, purchase decision making

\section{PENDAHULUAN}

Data riset kesehatan dasar tahun 2010 menyebutkan balita yang kekurangan gizi mencapai 17,9 persen. Kasus kekurangan gizi ini sebanyak 13 persen berstatus gizi kurang dan 4,9 persen berstatus gizi buruk. Keadaan ini berpengaruh pada masih tingginya angka kematian anak. Berdasarkan data tersebut, pemenuhan kebutuhan gizi bagi anak perlu diperhatikan. Untuk melengkapi kebutuhan gizi ini, susu pertumbuhan memegang peran penting untuk mengoptimalkan pertumbuhan dan perkembangan anak.
Susu merupakan minuman yang sangat bermanfaat karena banyak mengandung nutrisi yang dibutuhkan manusia. Susu mengandung lebih banyak vitamin dan mineral esensial yang dibutuhkan manusia dibanding jenis makanan lain. Dengan meminum susu dua gelas per hari akan meningkatkan daya konsentrasi dan kebugaran tubuh karena kandungan protein dalam susu yang mencukupi. Susu sebagai salah satu komoditi dengan kandungan gizi yang tinggi, diperlukan oleh masyarakat untuk meningkatkan pertumbuhan tulang dan kesehatan tubuh. Susu dikonsumsi selain dalam bentuk susu murni juga dikonsumsi 
dalam bentuk susu olahan, seperti susu bubuk, susu kental manis, susu formula dan susu cair yang telah diolah.

Saat anak menginjak usia balita pemenuhan gizi merupakan suatu keharusan untuk menunjang pertumbuhannya. Pada usia ini anak mengalami pertumbuhan dan perkembangan yang sangat pesat. Di sisi lain, setelah anak berusia satu tahun, air susu ibu hanya memenuhi 30 persen dari kebutuhan gizi anak. Untuk memenuhi kekurangan zat gizi tersebut perlu adanya asupan gizi tambahan, salah satunya adalah susu. Susu mengandung lemak, protein, berbagai mineral dan vitamin. Mengonsumsi susu sebanyak 500-600 cc dalam sehari cukup untuk memenuhi kebutuhan gizi anak.

Jumlah penduduk balita berdasarkan hasil pendataan BKKBN tahun 2010 adalah 18.376.394 anak. Propinsi Jawa Barat tercatat memiliki jumlah balita terbanyak yaitu 2.680.231 anak diikuti propinsi Jawa Timur 1.940.198 anak dan Jawa Tengah 1.923.939 anak. Sementara jumlah balita berdasarkan persentasenya terhadap jumlah total penduduk, tertinggi pertama adalah kepulauan Riau $(9,39$ persen), lalu kemudian diikuti Nusa Tenggara Timur dan Papua Barat masing-masing 8,16 persen dan 8,07 persen. Depkes dalam Laporan Data Penduduk Sasaran Program Pembangunan Kesehatan 2011-2014 (2011) melaporkan bahwa pada tahun 2011 estimasi jumlah penduduk balita adalah sebanyak 18.547.312 anak. Estimasi jumlah ini terus meningkat di tahun 2012 dan 2013 masingmasing 18.823.667 anak dan 19.104.139 anak.

Morey (2011) menyatakan bahwa pada tahun tahun 2008 konsumsi susu bubuk di Indonesia mencapai 179.370 ton, dan diramalkan akan meningkat 7,17 persen/tahun dan pada tahun 2013 akan mencapai angka 252.644 ton. Trend konsumsi rata-rata per kapita setahun susu bubuk balita di Indonesia mengalami peningkatan di tahun 2007-2011. Dibandingkan susu kental manis dan susu bubuk konvensional, susu bubuk balita mengalami peningkatan 3,43 persen. Susu kental manis dan susu bubuk mengalami penurunan masing-masing 1,61 persen dan 4,49 persen (Survei Sosial Ekonomi Nasional, 2007-2011).

The Organization of Economic Cooperation and Development diacu dalam Slette \& Meylinah (2012) memperkirakan di tahun 2013 produk domestik bruto (GDP) Indonesia akan tumbuh sebanyak 6 persen.
Hal ini diantaranya disebabkan oleh iklim politik yang stabil, bertambahnya konsumsi susu per kapita dan meningkatnya kesadaran masyarakat Indonesia tentang kesehatan. Kondisi ini akan memberikan kesempatan untuk pelaku industri susu di Indonesia untuk meningkatkan kapasitas produksinya.

Tingginya jumlah balita di Indonesia, membuat Indonesia menjadi salah satu pasar utama dalam pemasaran susu pertumbuhan dunia. Indonesia bersama China merupakan negara dengan konsumsi susu pertumbuhan terbesar di dunia. Food and Agriculture Organization of the United Nations (2012) dalam laporannya menyebutkan bahwa konsumsi susu balita di Indonesia merupakan yang tertinggi ke-2 di Asia dengan total 130.600 ton di tahun 2010. Persaingan susu pertumbuhan di Indonesia diperkirakan akan terus meningkat seiring dengan meningkatnya daya beli masyarakat dan meningkatnya kebutuhan masyarakat pada umumnya.

Persaingan industri susu mengakibatkan banyak beredar berbagai macam susu bubuk pertumbuhan. Persaingan ini menciptakan berbagai macam informasi terkait produk susu yang akan memengaruhi keputusan pembelian. Berbagai macam informasi yang beredar menyebabkan konsumen lebih mudah memperoleh informasi, namun tidak semua informasi yang disampaikan sesuai dengan kriteria yang diinginkan konsumen.

Dalam memilih produk yang akan dikonsumsi, konsumen mempertimbangkan berbagai macam faktor yang salah satunya adalah atribut produk. Berbagai informasi yang dimiliki konsumen terhadap berbagai macam atribut produk akan menenentukan konsumen dalam pengambilan keputusan. Menurut Istiqlal (2013) atribut-atribut produk dipandang sebagai faktor yang memengaruhi keputusan pembelian konsumen, yang mana semakin lengkap atribut sebuah produk, semakin besar peluang produk tersebut diminati oleh konsumen. Atribut yang sesuai dengan harapan dan manfaat yang dibutuhkan konsumen akan menjadi salah satu faktor pertimbangan konsumen dalam menentukan keputusan pembelian.

Penelitian mengenai faktor yang berpengaruh terhadap keputusan pembelian produk susu telah dilakukan Setiyanti, Maulana, dan Fahmi (2009) yang mengindikasikan bahwa faktor yang memengaruhi konsumen untuk mengonsumsi produk susu nutrisi adalah pengaruh dokter/ahli gizi, latar belakang pendidikan, pengeluaran per bulan, dan faktor 
ketersediaan produk. Sedangkan, faktor yang mendorong pakar menyarankan produk tersebut kepada orang lain meliputi harga, kelengkapan kandungan gizi, masa kadaluarsa yang panjang, ketersediaan produk, kejelasan informasi nilai gizi dan lainnya yang tercantum pada kemasan produk. Faktor pendapatan keluarga dan jumlah anak balita dalam keluarga berpengaruh terhadap peningkatan permintaan susu bubuk balita, sedangkan pendidikan ibu dan tingkat pengetahuan gizi ibu secara parsial tidak berpengaruh terhadap permintaan susu bubuk balita (Leko, Handayani, \& Budiraharjo, 2012). Penelitian yang dilakukan oleh Agza et al. (2013) pada produk susu dan olahan menunjukkan bahwa harga memberikan pengaruh yang paling besar dibandingkan dengan kualitas dan keamanan. Sementara itu, hasil penelitian Surota, Fanani, \& Nugroho (2013) menyebutkan bahwa harga tidak memiliki pengaruh terhadap keputusan pembelian susu di Kota Malang. Hasil penelitian tersebut menunjukkan beberapa faktor yang memberikan pengaruh terhadap keputusan pembelian yang dilakukan konsumen.

Berdasarkan uraian di atas penelitian ini dilakukan dengan tujuan untuk mengidentifikasi karakteristik responden pengguna susu bubuk pertumbuhan, menganalisis atribut-atribut produk apa yang menjadi pertimbangan responden pengguna rutin susu bubuk pertumbuhan.

\section{METODE}

Penelitian ini menggunakan desain cross sectional dengan metode survei. Penelitian dilakukan di Kota Jakarta. Lokasi penelitian dipilih secara purposive dengan pertimbangan bahwa Jakarta merupakan area dengan jumlah sales tertinggi dibandingkan dengan kota lainnya. Penelitian ini dilakukan pada bulan November 2013 sampai dengan bulan Februari 2014.

Teknik pengambilan contoh dalam penelitian ini dilakukan secara purposive sampling. Responden yang dipilih dengan kriteria memiliki balita dan berdomisili di Jakarta. Jumlah responden yang terlibat dalam penelitian ini adalah 140 orang dengan galat sebesar 10 persen yang mewakili populasi balita di kota Jakarta.

Pengumpulan data primer dilakukan melalui penyebaran kuesioner yang dibagikan kepada responden. Data primer yang dikumpulkan diantaranya karakteristik responden. Karakteristik responden dalam penelitian ini meliputi jenis kelamin, usia, pendidikan, dan pengeluaran (Rp/bulan) untuk membeli susu pertumbuhan. Adapun atribut produk yang diteliti dalam penelitian ini adalah harga, volume (isi), kemasan, aroma, varian rasa, komposisi dan nilai gizi, efek dan manfaat pada anak, keamanan produk, merek, promosi, kejelasan tanggal kadaluarsa, tercantumnya label halal, izin dari depkes, dan kemudahan memperoleh. Selain itu, dalam penelitian ini juga dilihat faktor lain yang diduga memengaruhi keputusan pembelian konsumen yang meliputi sumber informasi produk, tempat pembelian, dan sikap konsumen terhadap produk jika produk yang dicari tidak ada.

Penelitian ini menggunakan beberapa tahap analisis data. Tahapan analisis yang pertama adalah analisis cochran. Analisis cochran dimaksudkan untuk menguji atributatribut produk yang diteliti, apakah dapat diterima sebagai atribut yang melekat pada produk. Tahapan selanjutnya adalah uji validitas dan reliabilitas. Uji validitas dan reliabilitas bertujuan untuk menyatakan sejauh mana data yang ditampung pada suatu kuesioner akan mengukur apa yang ingin diukur. Analisa deskriptif digunakan untuk mengidentifikasi karakteristik konsumen dalam memilih susu bubuk pertumbuhan. Regresi logistik digunakan untuk mengetahui faktorfaktor karakteristik konsumen dan atribut produk (variabel bebas) yang berpengaruh signifikan terhadap pemilihan susu bubuk pertumbuhan (variabel terikat).

\section{HASIL}

\section{Karakteristik Konsumen}

Karakteristik konsumen yang diukur pada penelitian ini adalah jenis kelamin, usia, dan tingkat pendidikan. Berdasarkan hasil penelitian, jumlah wanita jauh lebih tinggi dibanding pria. Konsumen pria sebanyak 22 persen dan konsumen perempuan sebanyak 78 persen. $\mathrm{Hal}$ ini menunjukkan bahwa pengambilan keputusan penggunaan susu pertumbuhan didominasi oleh wanita. Jumlah konsumen susu pertumbuhan berdasarkan jenis kelamin dapat dilihat pada Tabel 1 .

Berdasarkan usia, hasil penelitian menunjukkan bahwa konsumen pengguna rutin susu pertumbuhan didominasi oleh rentang usia 26-35 tahun. Pada rentang usia ini jumlah responden mencapai 65 persen. Pada rentang 17-25 tahun 5 persen, usia 36-45 tahun sebanyak 25 persen, usia 46-55 tahun 
Jur. IIm. Kel. \& Kons.

sebanyak 4 persen dan pada usia 56-65 tahun sebanyak 1 persen. Karakteristik pengguna rutin susu pertumbuhan berdasarkan usia disajikan pada Tabel 1.

Berdasarkan hasil penelitian rata-rata konsumen pengguna rutin susu pertumbuhan berpendidikan sarjana yaitu sebanyak 54,0 persen. Selain tingkat pendidikan sarjana, tingkat pendidikan konsumen pengguna rutin susu pertumbuhan juga tersebar pada tingkat pendidikan akademi sebanyak 24,0 persen, pascasarjana sebanyak 13,0 persen, SMA sebanyak 8,0 persen dan SMP sebanyak 1 persen. Karakteristik pengguna rutin susu pertumbuhan berdasarkan tingkat pendidikan dapat dilihat pada Tabel 1.

Berdasarkan hasil penelitian, pengeluaran per bulan untuk konsumsi susu pertumbuhan sebanyak 39,0 persen konsumen sebesar Rp500.000,00-Rp750.000,00/bulan. Sebanyak 32,0 persen konsumen juga mengeluarkan uang sebesar Rp750.000,00-Rp1.000.000,00/ bulan. Sebanyak 19,0 persen konsumen juga mengeluarkan uang kurang dari Rp500.000,00 memperoleh proporsi 19 persen dan pengeluaran lebih dari Rp1.000.000,00 dikeluarkan oleh 10 persen konsumen (Tabel 1).

Tabel 1 Sebaran konsumen susu pertumbuhan berdasarkan jenis kelamin, usia, tingkat pendidikan, dan pengeluaran

\begin{tabular}{lr}
\hline Karakteristik & Persentase (\%) \\
\hline Jenis kelamin & 22 \\
Pria & 78 \\
Wanita & 100 \\
Total & \\
\hline Usia (tahun) & 5,0 \\
$17-25$ & 65,0 \\
$26-35$ & 25,0 \\
$36-45$ & 4,0 \\
$46-55$ & 1,0 \\
$56-65$ & 100,0 \\
Total & \\
\hline Tingkat pendidikan & 1,0 \\
SMP & 8,0 \\
SMA & 24,0 \\
Akademi & 54,0 \\
Sarjana & 13,0 \\
Pascasarjana & 100,0 \\
Total & 19,0 \\
\hline Pengeluaran (Rp/bulan) & 39,0 \\
< 500.000,00 & 32,0 \\
$500.000,00-750.000,00$ & 10,0 \\
$750.000,00-1.000 .000,00$ & 100,0 \\
>1.000.000,00 &
\end{tabular}

\section{Atribut Susu Pertumbuhan yang Dipertimbangkan Konsumen}

Uji cochran dan uji validitas dan reliabilitas dilakukan untuk mengetahui faktor-faktor yang memengaruhi keputusan penggunaan susu pertumbuhan. Uji cochran dilakukan pada 14 atribut yaitu harga, volume (isi), kemasan, aroma, varian rasa, komposisi dan nilai gizi, efek dan manfaat pada anak, keamanan produk, merek, promosi, kejelasan tanggal kadaluarsa, tercantumnya label halal, izin di depkes, dan kemudahan memperoleh. Berdasarkan hasil analisis menggunakan SPSS dengan melakukan iterasi sebanyak 5 kali, didapatkan $p$-value bernilai >0,05 menghasilkan delapan atribut yang dianggap penting serta dipertimbangkan oleh konsumen. Atribut-atribut tersebut adalah varian rasa, komposisi dan nilai gizi, efek dan manfaat pada anak, keamanan produk, kejelasan tanggal kadaluarsa, label halal, izin di depkes, dan kemudahan memperoleh. Delapan atribut ini selanjutnya digunakan untuk tahapan analisis pendahuluan selanjutnya yaitu uji validitas dan reliabilitas.

Berdasarkan uji validitas atribut varian rasa memiliki nilai $r_{\text {hitung }}=0,301$. Nilai $r_{\text {tabel }}$ pada penelitian ini adalah 0,361. Karena nilai tersebut $<r_{\text {tabel }}$, maka atribut varian rasa dinyatakan tidak valid dan dieliminasi. Kemudian dilakukan analisis ulang yang hanya mengukur komposisi dan nilai gizi, efek dan manfaat pada anak, keamanan produk, kejelasan tanggal kadaluarsa, tercantumnya label halal, izin depkes, dan kemudahan memperoleh. Hasil analisis ulang menunjukkan ke-7 atribut memiliki nilai $r_{\text {hitung }}>r_{\text {tabel, }}$ sehingga dapat dinyatakan ke-7 atribut tersebut valid. Hasil pengolahan uji reliabilitas untuk ke-7 atribut produk tersebut ditunjukkan oleh nilai Cronbach's alpha sebesar 81,2 persen yang berarti ke-7 atribut tersebut sangat reliabel.

Faktor komposisi dan nilai gizi. Berdasarkan hasil analisis regresi logistik, komposisi dan nilai gizi berpengaruh signifikan terhadap keputusan pembelian susu bubuk pertumbuhan. Hal ini ditunjukkan oleh $p$-value sebesar 0,008. Nilai ini berarti komposisi dan nilai gizi berpengaruh signifikan pada tingkat $\alpha=10 \%$. Odd ratio atribut komposisi dan nilai gizi yaitu 14,832 . Bila nilai odd ratio ini dimasukkan kedalam $\mathrm{p} /(1-\mathrm{p})$ maka peluang seorang pelanggan memilih menggunakan susu pertumbuhan yang disebabkan faktor atribut komposisi dan nilai gizi adalah sebesar 93,7 persen. Koefisien regresi logistik untuk atribut komposisi dan nilai gizi yaitu 2,697. Koefisien regresi logistik yang bernilai positif ini 
sesuai dengan dugaan hipotesis. Nilai ini menunjukkan, dengan menganggap variabel lain konstan, komposisi dan nilai gizi yang lebih tinggi pada susu pertumbuhan akan memengaruhi pelanggan untuk memutuskan menggunakan susu pertumbuhan 14,832 kali. Secara kualitatif dapat dikatakan bahwa semakin bergizi susu pertumbuhan menurut persepsi pelanggan maka akan semakin memperbesar peluang pelanggan tersebut menggunakan susu pertumbuhan. Pengaruh signifikan positif yang dihasilkan berdasarkan analisa regresi logistik ini membuktikan hipotesis sebelum penelitian yang mana komposisi dan nilai gizi dihipotesiskan akan meningkatkan peluang penggunaan susu pertumbuhan.

Faktor efek dan manfaat pada anak. Berdasarkan hasil analisis regresi logistik efek dan manfaat susu pertumbuhan pada anak mempunyai pengaruh yang positif signifikan terhadap keputusan penggunaan susu pertumbuhan. Hal ini ditunjukkan oleh $p$-value sebesar 0,015 dan nilai koefisien regresi logistik 2,896 . Nilai $p$-value menunjukkan faktor efek dan manfaat pada anak berpengaruh signifikan pada tingkat $\alpha=10 \%$. Odd ratio atribut efek dan manfaat pada anak mencapai 18,106. Dengan melihat koefisien regresi logistik untuk atribut efek dan manfaat pada anak, menunjukkan bahwa dengan menganggap variabel yang lain konstan, susu pertumbuhan yang memberikan efek dan manfaat yang positif bagi balita akan meningkatkan peluang keputusan penggunaan susu bubuk pertumbuhan 18,106 kali. Secara kualitatif dapat dikatakan bahwa semakin baik efek yang dihasilkan susu pertumbuhan terhadap balita, maka semakin tinggi peluang seorang pelanggan untuk menggunakan susu pertumbuhan. Nilai odd ratio bila disubtitusikan pada model logit dan dengan mengabaikan variabel lain, maka pengaruh efek dan manfaat pada anak memberikan kontribusi sebesar 94,8 persen terhadap keputusan penggunaan susu pertumbuhan.

Faktor keamanan produk. Berdasarkan hasil analisis regresi logistik, faktor atribut keamanan produk berpengaruh signifikan terhadap keputusan pembelian susu bubuk pertumbuhan. Hal ini ditunjukkan oleh $p$-value sebesar 0,079. Nilai ini berarti keamanan produk berpengaruh signifikan pada tingkat $\alpha=10 \%$. Odd ratio atribut keamanan produk adalah 2,558. Bila nilai odd ratio ini dimasukkan kedalam $p /(1-p)$ maka peluang seorang pelanggan memilih menggunakan susu pertumbuhan yang disebabkan faktor atribut keamanan produk adalah sebesar 71,9 persen.
Dengan kata lain, peran kemanan produk adalah 71,9 persen dalam memengaruhi seorang pelanggan untuk memutuskan menggunakan susu pertumbuhan. Nilai ini juga dapat diinterpretasikan bahwa jika ada 100 orang yang memutuskan untuk menggunakan susu pertumbuhan maka 72 orang diantaranya dipengaruhi oleh faktor kemanan produk. Dengan melihat koefisien regresi logistik untuk atribut keamanan produk yaitu 0,939 . Nilai ini menunjukkan bahwa dengan menganggap variabel yang lain konstan, semakin aman produk susu pertumbuhan menurut persepsi pelanggan akan meningkatkan peluang pembelian susu bubuk pertumbuhan 2,558 kali lebih tinggi dibandingkan produk yang tidak aman.

Faktor tanggal kadaluarsa. Berdasarkan hasil analisis regresi logistik, faktor atribut tanggal kadaluarsa tidak berpengaruh signifikan terhadap keputusan pembelian susu bubuk pertumbuhan. Hal ini ditunjukkan oleh $p$-value sebesar 0,904.

Label halal. Berdasarkan hasil analisis regresi logistik, faktor atribut label halal tidak berpengaruh signifikan terhadap keputusan pembelian susu bubuk pertumbuhan. Hal ini ditunjukkan oleh $p$-value sebesar 0,864 . Nilai ini tidak berpengaruh signifikan pada tingkat $\alpha=10,0 \%$.

Terdaftar di Depkes. Berdasarkan hasil analisis regresi logistik, faktor atribut label halal tidak berpengaruh signifikan terhadap keputusan pembelian susu bubuk pertumbuhan. Hal ini ditunjukkan oleh $p$-value sebesar 0,939. Nilai ini tidak berpengaruh signifikan pada tingkat $\alpha=10,0 \%$.

Kemudahan memperoleh. Berdasarkan hasil analisis regresi logistik, faktor kemudahan memperoleh berpengaruh signifikan terhadap keputusan pembelian susu bubuk pertumbuhan. Hal ini ditunjukkan oleh $p$-value sebesar 0,086. Nilai ini berarti keamanan produk berpengaruh signifikan pada tingkat $\alpha=10,0 \%$. Odd ratio atribut kemudahan memperoleh adalah 1,117. Nilai odd ratio bila disubtitusikan pada model logit dan dengan mengabaikan variabel lain, maka pengaruh kemudahan memperoleh memberikan kontribusi sebesar 52,8 persen terhadap keputusan penggunaan susu pertumbuhan. Selain itu, nilai 52,8 persen dapat juga diinterpretasikan bahwa jika ada 100 orang yang memutuskan menggunakan susu pertumbuhan, 53 orang diantaranya di-pengaruhi oleh faktor kemudahan memperoleh. Dengan melihat 
koefisien regresi logistik untuk atribut komposisi dan nilai gizi yaitu 0,111 . Nilai ini menunjukkan bahwa dengan menganggap variabel yang lain konstan, kenaikan persepsi pelanggan tentang kemudahan memperoleh produk akan meningkatkan peluang pembelian susu bubuk pertumbuhan 1,117 kali. Secara kualitatif dapat dikatakan bahwa semakin mudah susu pertumbuhan diperoleh, maka semakin tinggi peluang seorang pelanggan untuk menggunakan susu pertumbuhan.

Sumber informasi. Sumber informasi yang paling memengaruhi konsumen dalam membeli susu pertumbuhan adalah berdasarkan informasi dari keluarga atau teman dengan persentase 35 persen. Selain berdasarkan informasi keluarga dan teman, sumber informasi yang juga sangat memengaruhi konsumen dalam membeli susu bubuk pertumbuhan adalah iklan TV dengan persentase 31 persen. Anjuran dokter menjadi alternatif sumber informasi yang cukup memengaruhi konsumen dalam membeli susu bubuk pertumbuhan dengan persentase 25 persen. Sumber informasi lain yang menjadi acuan konsumen dalam membeli susu bubuk pertumbuhan diantaranya adalah melalui SPG atau wiraniaga ditempat pembelian, melalui majalah atau tabloid, melalui website dan melalui buku. Hasil penelitian terkait sumber informasi yang paling memengaruhi pembelian susu bubuk pertumbuhan disajikan pada Tabel 2.

Tempat pembelian. Berdasarkan tempat pembelian, 96 persen responden memilih hypermarket, supermarket dan minimarket sebagai tempat pembelian susu bubuk pertumbuhan. Hal ini dimungkinkan karena hypermarket, supermarket dan minimarket berada di daerah yang sangat mudah dijangkau oleh konsumen, harga yang lebih murah dan tempat berbelanja yang nyaman. Hasil ini juga mendukung bahwa susu bubuk pertumbuhan dalam distribusinya di-lakukan di modern trade seperti hypermarket, supermarket dan minimarket. Selain hypermarket, supermarket dan minimarket, tempat pembelian lainnya yang juga menjadi pilihan bagi konsumen adalah di pasar tradisional dan grosir. Menurut hasil penelitian Yoso (2006) hal ini dimungkinkan karena hypermarket, supermarket, dan minimarket berada di daerah yang sangat mudah dijangkau oleh pelanggan, harga yang lebih murah dan tempat berbelanja yang nyaman tempat pembelian yang menjadi acuan konsumen dirangkum pada Tabel 2.
Tabel 2 Sumber informasi dan tempat pembelian susu bubuk pertumbuhan

\begin{tabular}{lr}
\hline Kelompok & Persentase (\%) \\
\hline Sumber informasi & \\
Keluarga/ teman & 35,0 \\
Iklan TV & 31,0 \\
Dokter & 25,0 \\
Lain-lain & 9,0 \\
Total & 100,0 \\
\hline Tempat pembelian & \\
Hypermarket/supermarket/ & 96,0 \\
Minimarket & \\
Pasar tradisional & 3,0 \\
Grosir & 1,0 \\
Total & 100,0 \\
\hline
\end{tabular}

\section{Sikap Konsumen jika Produk yang Dicari Tidak Ada}

Konsumen susu bubuk pertumbuhan merupakan konsumen yang loyal terhadap merek produk yang telah menjadi pilihannya. Hasil penelitian menunjukkan bahwa konsumen memilih mencari ke tempat lain apabila susu pertumbuhan yang dicari tidak ada. Persentase konsumen dengan tipe seperti ini mencapai 77 persen (Tabel 3). Hal ini mendukung hasil penelitian Yoso et al. (2006) yang menyebutkan bahwa tingkat loyalitas pelanggan susu bubuk pertumbuhan sangat tinggi.

\section{Merek Top of Mind}

Merek susu pertumbuhan yang menjadi top of mind menggambarkan merek susu pertumbuhan yang pertama kali diingat oleh konsumen saat disebutkan susu pertumbuhan. Berdasarkan hasil penelitian deskriptif yang disajikan pada Tabel 4 memberikan keterangan bahwa merek susu bubuk pertumbuhan yang paling diingat oleh konsumen yaitu 27 persen menyatakan merek Dancow merupakan top of mind, kemudian merek SGM dan Nutricia dengan persentase yang sama yaitu 20 persen. Top of mind selanjutnya diikuti oleh susu pertumbuhan merek Frissian Flag 7 persen dan Sustagen, Morinaga dan Enfagrow dengan persentase masing-masing 5 persen.

Tabel 3 Sikap konsumen bila produk susu pertumbuhan yang dicari tidak ada

\begin{tabular}{lr}
\hline Sikap & Persentase (\%) \\
\hline Tetap membeli produk & 77,0 \\
tersebut di tempat lain & \\
Membeli produk merek & 17,0 \\
lain & \\
Tidak jadi membeli & 6,0 \\
\hline Total & 100,0 \\
\hline
\end{tabular}


Tabel 4 Top of mind merek susu bubuk pertumbuhan di Jakarta

\begin{tabular}{lr}
\hline Merek & Persentase (\%) \\
\hline Dancow & 27,0 \\
SGM & 20,0 \\
Nutricia & 20,0 \\
Frisian flag & 7,0 \\
Sustagen & 5,0 \\
Enfragow & 5,0 \\
S-26 & 3,0 \\
Morinaga & 5,0 \\
Biokids & 2,0 \\
Prediasure & 2,0 \\
Lain-lain & 4,0 \\
\hline Total & 100,0 \\
\hline
\end{tabular}

\section{Faktor-Faktor yang Memengaruhi Keputus-} an Penggunaan Susu Bubuk Pertumbuhan

Hasil uji nilai probabilitas HosmerLemeshow untuk model logit keputusan penggunaan susu bubuk pertumbuhan adalah 0,306 (Tabel 5), nilai ini $>0,10$ yang menujukkan bahwa model sesuai dan tidak ada perbedaan yang signifikan antara hasil observasi dengan kemungkinan prediksi model. Uji likelihood pada penelitian ini menunjukkan nilai -2 log likelihood pada block $=0$ bernilai 148,77 dan nilai pada block $=1$ bernilai 101,28 sehingga dapat dikatakan bahwa model yang dihipotesiskan fit dengan data.

Tabel 5 Variabel yang memengaruhi konsumen dalam mengambil keputusan penggunaan susu bubuk pertumbuhan

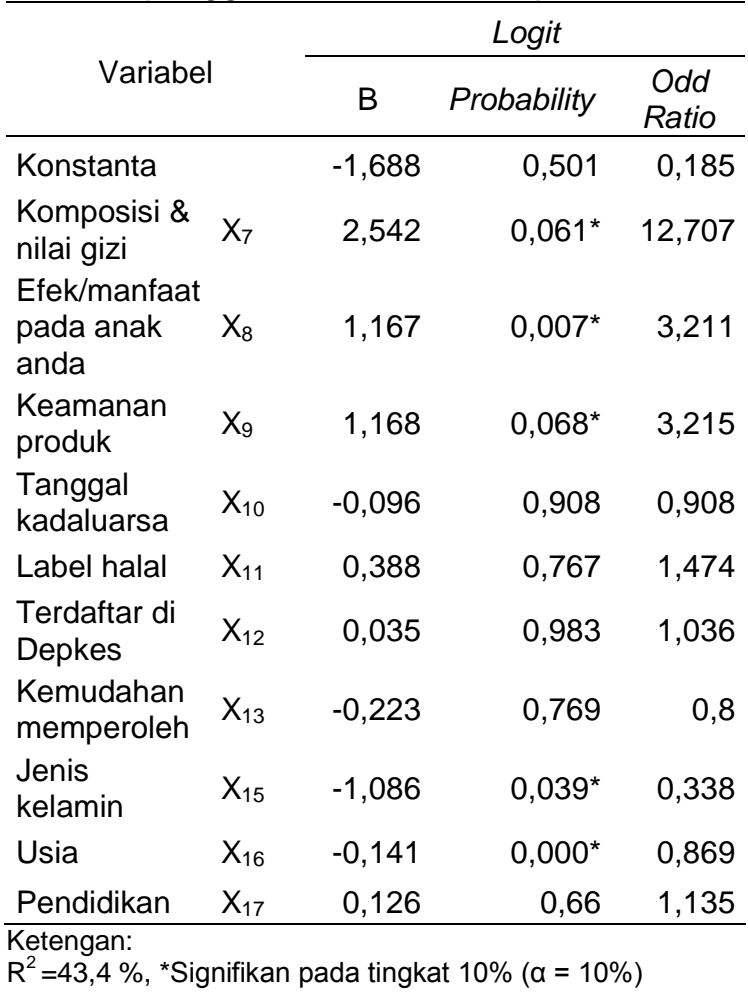

Berdasarkan Tabel 9, variabel independen yang berpengaruh positif signifikan terhadap keputusan pembelian susu bubuk pertumbuhan adalah komposisi dan nilai gizi, faktor efek dan manfaat pada anak, dan keamanan produk. Sementara variabel usia dan variabel jenis kelamin berpengaruh negatif signifikan. Sementara itu, variabel tingkat pendidikan, kejelasan tanggal kadaluarsa, tercantumnya label halal, izin dari Departemen Kesehatan, dan kemudahan memperoleh tidak berpengaruh signifikan.

Berdasarkan hasil analisis regresi logistik yang disajikan pada Tabel 5, persamaan logit dapat dituliskan sebagai berikut:

$$
\begin{aligned}
\ln \frac{p}{1-p}= & -1,69+2,54 X_{7}+1,17 X_{8}+1,17 X_{9}-0,10 X_{10^{+}} \\
& 0,39 X_{11}+0,04 X_{12}-0,22 X_{13}-1,09 X_{15}-0,14 X_{16}+ \\
& 0,13 X_{17}
\end{aligned}
$$

\section{PEMBAHASAN}

Berdasarkan hasil penelitian, karakteristik konsumen pengguna susu bubuk pertumbuhan menunjukkan bahwa pengambilan keputusan pembelian cenderung dilakukan oleh wanita $(78,0 \%)$ dari pada pria $(22,0 \%)$ dengan rentang usia 26-35 tahun $(65,0 \%)$. Tingkat pendidikan terakhir konsumen pengguna susu bubuk pertumbuhan terbanyak (54,0\%) adalah sarjana. Pengeluaran konsumen untuk susu bubuk pertumbuhan terbanyak $(39,0 \%)$ berada pada rentang Rp500.000-Rp750.000 per bulan.

Hipotesis dugaan pada penelitian adalah variabel pendidikan, komposisi dan nilai gizi, efek dan manfaat pada anak, keamanan produk, kejelasan dan kemudahan mencari tanggal kadaluarsa, tercantumnya label halal, terdaftar di Departemen Kesehatan dan kemudahan memperoleh diduga akan berpengaruh signifikan positif terhadap keputusan penggunaan susu pertumbuhan. Sedangkan variabel usia dan Jenis kelamin diduga akan berpengaruh signifikan negatif terhadap keputusan penggunaan susu pertumbuhan.

Berdasarkan hasil analisis regresi logistik, komposisi dan nilai gizi berpengaruh signifikan terhadap keputusan pembelian susu bubuk pertumbuhan. Hasil analisis ini sesuai dengan hipotesis penelitian yang mana faktor komposisi 
dan nilai gizi dihipotesiskan berpengaruh signifikan positif terhadap keputusan untuk mengonsumsi susu pertumbuhan. Produk susu yang berkualitas tinggi cenderung akan dipilih konsumen untuk dikonsumsi (Hartono, Utami, \& Amanullaili, 2010). Hasil penelitian Hsu dan Lin (2006) menyatakan bahwa kandungan/ komposisi (lemak dan protein) pada produk susu merupakan salah satu pertimbangan konsumen dalam memilih produk susu. Kandungan nilai gizi merupakan atribut utama yang dipertimbangkan konsumen dalam memilih jenis susu (Hidayat, Sumarwan, \& Yuliati, 2008).

Variabel efek dan manfaat pada anak juga berpengaruh positif terhadap keputusan penggunaan susu bubuk pertumbuhan dan signifikan. Pengaruh ini sesuai dengan hipotesis penelitian yang mana susu pertumbuhan yang memberikan efek dan manfaat yang positif bagi balita sehingga akan meningkatkan peluang keputusan penggunaan susu bubuk pertumbuhan. Hasil penelitian ini didukung oleh yang dilakukan Maesaroh (2003) yang menyatakan bahwa faktor kecocokan pada anak dalam pemilihan susu formula lebih dipentingkan dibandingkan atribut produk kelengkapan gizi, rekomendasi dokter merek, ukuran kemasan dan harga.

Dalam mengambil keputusan untuk menggunakan susu pertumbuhan, konsumen akan melihat faktor kecocokan susu pertumbuhan tersebut pada balitanya. Efek dan manfaat pada anak menurut konsumen lebih diartikan sebagai faktor kecocokan susu pertumbuhan tersebut bila dikonsumsi pada anak. Faktor efek dan manfaat pada anak sangat tergantung pada formulasi ingredient yang terkandung pada susu bubuk pertumbuhan yang dipasarkan. Formulasi ingredient ini kemudian harus disesuaikan dengan karakteristik dari balita. Hasil ini juga diperkuat berdasarkan penelitian Putri (2012) bahwa manfaat yang diharapkan dari kandungan nutrisi dalam susu pertumbuhan diantaranya adalah dapat meningkatkan daya tahan tubuh, kesehatan percernaan anak, perkembangan otak anak, dan membantu tumbuh kembang optimal pada anak.

Faktor lain yang juga berpengaruh signifikan positif terhadap keputusan pembelian susu bubuk pertumbuhan adalah faktor keamanan produk. Faktor keamanan produk akan meningkatkan peluang orang tua untuk menggunakan susu pertumbuhan sebagai asupan gizi tambahan untuk balitanya. Green et al. (2005); Angula, Ana, \& Gil (2007) menegaskan bahwa risiko keamanan pangan menjadi faktor pertimbangan konsumen dalam menentukan produk pangan yang akan dikonsumsi. Hasil penelitian ini sesuai dengan penelitian sebelumnya yang dilakukan oleh Novoselova, Meuwisswem, \& Van der Lans (2002) bahwa konsumen yang memiliki anak lebih memperhatikan keamanan produk susu dan bersedia untuk membayar dengan harga lebih tinggi untuk produk extra-safe milk.

Variabel lain yang juga signifikan tetapi berpengaruh negatif terhadap keputusan pembelian adalah usia dan jenis kelamin. Hal ini sesuai dengan hipotesis penelitian, yang mana semakin muda usia konsumen semakin tinggi peluangnya untuk menggunakan susu pertumbuhan. Konsumen berjenis kelamin wanita memiliki peluang yang lebih tinggi dalam mengambil keputusan untuk mengonsumsi susu pertumbuhan dibanding konsumen berjenis kelamin pria.

Faktor yang memengaruhi responden dalam memilih susu bubuk pertumbuhan adalah faktor komposisi dan nilai gizi. Sejalan dengan hasil penelitian Hidayat, Sumarwan, dan Yuliati (2009) bahwa salah satu atribut yang diutamakan konsumen dalam memutuskan pembelian susu formula adalah klaim gizi. Konsumen cenderung memilih kandungan zat gizi yang dianggap memiliki klaim gizi terbaik. Terkait hal ini bagian pemasar dapat melakukan edukasi konsumen mengenai nilai penting komposisi dan nilai gizi yang terkandung pada susu bubuk pertumbuhan.

Pemasar melalui perusahaannya dapat melakukan reformulasi kandungan zat dalam susu bubuk pertumbuhan sehingga dapat mengonsumsi susu bubuk pertumbuhan tanpa menimbulkan efek yang tidak diharapkan bagi balita yang mengonsumsinya untuk memenuhi kebutuhan konsumen dalam konsumsi susu bubuk pertumbuhan yang menghasilkan efek dan manfaat yang positif pada anak. Pemasar harus mengikuti persyaratan dan perizinan depkes dan BPOM untuk memastikan bahwa produk yang dipasarkan adalah produk yang aman untuk dapat dipercaya oleh konsumen bahwa susu bubuk pertumbuhan yang dipasarkan adalah produk yang aman dikonsumsi. 


\section{SIMPULAN DAN SARAN}

Karakteristik responden yang memutuskan untuk menggunakan susu bubuk pertumbuhan sebagai asupan gizi tambahan bagi balitanya berada pada rentang usia 26-35 tahun dengan tingkat pendidikan minimal akademi, berjenis kelamin wanita dan dengan jumlah pengeluaran per bulan yang digunakan untuk konsumsi susu pertumbuhan adalah sebesar Rp500.000,00Rp1.000.000,00. Berdasarkan hasil analisis logistik, disimpulkan faktor yang signifikan berpengaruh dalam keputusan menggunakan susu pertumbuhan sebagai asupan gizi tambahan bagi balitanya adalah komposisi dan nilai gizi, faktor efek dan manfaat pada anak, dan keamanan produk.

Prioritas strategi yang dapat dilakukan oleh pemasar susu bubuk pertumbuhan adalah dengan mengedukasi konsumen tentang nilai penting komposisi dan nilai gizi yang terkandung pada susu bubuk pertumbuhan, mereformulasi kandungan zat dalam susu bubuk pertumbuhan sehingga menghasilkan efek yang positif bagi balita yang mengonsumsinya dan mengikuti persyaratan dan perizinan depkes dan BPOM untuk memastikan bahwa produk yang dipasarkan adalah produk yang aman.

\section{DAFTAR PUSTAKA}

Agza, B., Mellese, K., Funga, A., \& Mallese, K. (2013). Assessment of knowledge gap and factors affecting consumption of dairy products in Ada'a an Lume districts of East Showa Zone, Ethiopia. African Journal of Food Science and Technology, 4(9), 201$210 . \quad$ Diambil dari http://www.intersjournal.org/AJFST. [diunduh 6 Okt 2013].

Angulo, Ana, M., \& Gil, J. M. (2007). Risk perception and consumer willingness to pay for certified beef in Spain. Food Quality and Preference, 18(8), 1106-1117.

[BKKBN] Badan Kependudukan dan Keluarga Berncana Nasional. (2010). Direktorat Pelaporan dan Statistik: Hasil pendataan keluarga tahun 2010. Jakarta, ID: BKKBN.

[Depkes] Departemen Kesehatan. (2011). Data penduduk sasaran program pembangunan kesehatan 2011-2014. Pedoman pelayanan anak gizi buruk Jakarta, ID: Depkes.

[FAO] Food and Agriculture Organization of the United Nations. (2012). Codex Committee On Nutrition And Foods For Special Dietary Uses. New Zealand.

Green, Judith, M., Alizon, K., Draper, Elizabeth A., Dowler, Giolo Fele, Hagenhoff, V., Rusanen, M., \& Rusanen, T. (2005). Public understanding of food risks in four European countries: A qualitative study. The European Journal of Public Health, 15(5), 523-527.

Hartono, B., Utami, H. D., \& Amanatullaili, N. (2010). Analisis faktor-faktor yang memengaruhi konsumen dalam membeli produk susu. Buletin Peternakan, 34(2), 123-130.

Hidayat, I. K., Sumarwan, U., \& Yuliati, L. N. (2009). Persepsi dan sikap ibu terhadap klaim gizi dalam iklan susu formula lanjutan anak usia prsekolah dan hubungannya dengan keputusan pembelian. Jur.I IIm. Kel. dan Kons., 2(1), 77-85.

Hsu, J. L., \& Lin, Y. T. (2006). Consumption and attribute perception of fluid milk in Taiwan. Journal of Nutrition \& Food Science, 36(3), 177-182.

Istiqlal, A. H. (2013). Atribut produk dalam keputusan pembelian konsumen. Jurnal Ekonomi dan Manajemen, 1(1), 20-30.

Leko, J., Handayani, M., \& Budiraharjo, K. (2012). Analisis permintaan produk susu bubuk balita pada konsumen rumah tangga di Kecamatan Loli Kabupaten Sumba Barat. Animal Agricultural Journal, 1(1), 359-377.

Maesaroh, S. (2003). Analisis perilaku konsumen dalam pemilihan susu formula di rumah sakit ibu dan anak Hermina Jatinegara (tesis). Institut Pertanian Bogor, Bogor.

Morey, P. (2011). Indonesia dairy industry development. International Finance Corporation.

Novoselova, T., Meuwissem, M., \& Van der Lans, I. A. (2002). Consumer's perception of milk safety. Paper Presented at The $13^{\text {th }}$ International Farm Management Congress, Wageningen, The Netherlands. 
Putri, E. R. (2012). Analisis pembentukan sikap ibu terhadap iklan televisi susu pertumbuhan tanpa gula tambahan dan pengaruhnya terhadap niat membeli (tesis). Institut Pertanian Bogor, Bogor.

Setiyanti, E. S., Maulana, A., \& Fahmi, I. (2009). Strategi pemasaran produk susu nutrisi enteral klinikal. Jurnal Manajemen dan Agribisnis, 6(2), 110-123.

Slette, J., \& Meylinah, S. (2012). Indonesia dairy and products annual reports 2012.
Dairy and Products Annual. USDA Foreign Agricultural Service. Jakarta.

Surota, K. S., Fanani, Z., \& Nugroho, B. A. (2013). Factors influencing's purchase decision of formula milk in Malang City. Journal of Bussiness and Management, 9(3), 95-99.

Yoso. (2006). Kajian dan Evaluasi Strategi Pemasaran Untuk Mempertahankan Produk Procal dan Promise Sebagai Market Leader di Indonesia (tesis). Universitas Bina Nusantara, Jakarta. 